\title{
Chlorocarbonylsulfenyl Chloride Cyclizations Towards Piperidin-3-yl-oxathiazol-2-ones as Potential Covalent Inhibitors of Threonine Proteases
}

\author{
Marko Jukič, ${ }^{1}$ Katarina Grabrijan, ${ }^{1}$ Selmir Kadić, ${ }^{1}$ \\ Fernando Juan de Lera Garrido, ${ }^{1,2}$ Izidor Sosič, ${ }^{1}$ Stanislav Gobec ${ }^{1}$ and Aleš Obreza ${ }^{1, \star}$ \\ ${ }^{1}$ University of Ljubljana, Faculty of Pharmacy, Department of medicinal chemistry; Aškerčeva 7, \\ SI-1000, Ljubljana, Slovenia \\ ${ }^{2}$ Universidad de Castilla-La Mancha (Albacete); Universidad de Castilla-La Mancha, Altagracia, 50 \\ 13071 Ciudad Real, Spain \\ * Corresponding author: E-mail: ales.obreza@ffa.uni-lj.si \\ phone: +38614769 677; fax: +38614258031
}

Received: 29-09-2017

Dedicated to Professor Emeritus Miha Tišler, University of Ljubljana, on the occasion of his $\mathbf{9 0}^{\text {th }}$ birthday.

\begin{abstract}
Using rescaffolding approach, we designed piperidine compounds decorated with an electrophilic oxathiazol-2-one moiety that is known to confer selectivity towards threonine proteases. Our efforts to prepare products according to the published procedures were not successful. Furthermore we identified major side products containing nitrile functional group, resulting from carboxamide dehydration. We systematically optimized reaction conditions towards our desired products to identify heating of carboxamides with chlorocarbonylsulfenyl chloride and sodium carbonate as base in dioxane at $100{ }^{\circ} \mathrm{C}$. Our efforts culminated in the preparation of a small series of piperidin-3-yl-oxathiazol-2-ones that are suitable for further biological evaluation.
\end{abstract}

Keywords: Cyclization, amide dehydration, oxathiazole-2-one, threonine protease, covalent inhibitors, irreversible inhibition

\section{Introduction}

Proteases play key roles in complex biological systems and in multiple structural and signalling pathways. They constitute a historically important field in medicinal chemistry and continue to represent a source of potential drug targets. They are involved in the pathology of hypertension, autoimmune and inflammatory diseases, reperfusion injury, blood clotting disorders, HIV and other viral infections, parasitic and bacterial infections, and last but not least, cancer. ${ }^{1}$ Protease inhibitors are not valuable only as potential drugs but also as experimental tools for structural biology, ${ }^{2}$ as they can be used as molecular probes in the elucidation of protease structures and protease pathway mechanisms. ${ }^{3}$ Recently, databases of proteases (sometimes also termed peptidases, proteinases or proteolytic enzymes) have been established as a resource in this immense research field; namely the Merops database with over 4000 individual entries. ${ }^{4}$

Our research efforts are mainly focused on the $N$-terminal threonine proteases that form stable covalent acyl-enzyme complexes and are subsequently hydrolyzed to afford product peptides. Threonine proteases constitute 99 entries in the Merops database, where we specifically study the threonine-type endopeptidases, such as the proteasomes. ${ }^{5}$ The proteasomes consist of a central proteolytic unit, known as the $20 \mathrm{~S}$ proteasome, and the $19 \mathrm{~S}$ regulators, which together make up a $26 \mathrm{~S}$ structure (Figure 1). The constitutive isoform of the proteasome is expressed in all eukaryotic cells while its immunomodulatory isoform, the immunoproteasome, is mainly expressed in cells associated with the immune system, such as lymphocytes and 
monocytes. ${ }^{5,6}$ The constitutive proteasome contains three enzymatically active subunits, namely the b1c (caspaselike), the b2c (trypsin-like), and the $\beta 5 c$ (chymotrypsin-like) that are embedded into a barrel-shaped structure consisting of four rings of $\beta$-subunits and $\alpha$-subunits in an abba order. The immunoproteasome has essentially the same overall structure, only the catalytically active subunits of cCP are replaced by their counterparts b1i, b2i, and $\beta 5 \mathrm{i}$ (Figure 1). The $20 \mathrm{~S}$ proteasome core particle of both isoforms is a protease of $720 \mathrm{kDa}$ and 28 individual subunits and is responsible for essential proteolytic degradation during cellular inflammatory and oxidative stress. ${ }^{7}$ Immunoproteasome is also important for the generation of peptides for antigen presentation; moreover, recent studies also suggest a pleiotropic role in cellular function of the immunoproteasome. ${ }^{8-10}$

There is an amounting body of research on the small-molecule inhibitors of proteasomes. ${ }^{5,11}$ Both marketed medicines, bortezomib and carfilzomib, equally inhibit the catalytically active $\beta 5$ subunits of the constitutive proteasome and the immunoproteasome. The combined inhibition of both isoforms leads to cytotoxicity that limits the clinical application of these broad spectrum proteasome inhibitors. ${ }^{6}$ In addition, many of the investigational compounds are peptide-like compounds and this represents a serious limitation to their metabolic stability and bioavailability. ${ }^{5}$ To overcome these problems, multiple approaches can be found in literature: design of reversible proteasome inhibitors, ${ }^{12}$ use of structural differences in the binding sites of both proteasomes in structure-based drug design, ${ }^{13,14}$ design of highly selective and hydrolytically more stable peptidic compounds, ${ }^{15}$ design of highly selective non-peptidic compounds, ${ }^{16}$ use of non-catalytic residues or allosteric sites in inhibitor design, ${ }^{17}$ and the design of selective electrophilic warheads. ${ }^{18}$ The majority of these compounds are covalent irreversible inhibitors bearing an electrophilic warhead that is capable of reacting with the $\mathrm{N}$-terminal threonine residue in the catalytic active site of the examined protease. ${ }^{5,11}$ Electrophilic warheads belong to structural classes of aldehydes, $\alpha$ ', $\beta$ '-epoxyketones, $\alpha$-keto aldehydes, $\beta$-lactones, vinyl sulfones, Michael-acceptor systems, and boronates. ${ }^{19}$ The active interest in this field is clearly represented by a very recent publication, ${ }^{19}$ where a new mechanism for an existing warhead was reported, i.e. the formation of 1,4-oxazepane upon reaction of an $\alpha^{\prime}, \beta^{\prime}$-epoxyketone warhead with the $N$-terminal threonine rather than the previously reported morpholine ring. ${ }^{14,19}$ Such new developments provide invaluable data for the design of novel and selective irreversible inhibitors of threonine proteases.

In order to design targeted covalent inhibitors of threonine protease, we sought to examine the available electrophilic warheads. ${ }^{20}$ We were in particular interested in compounds that could provide a suitable reactivity and selectivity towards threonine proteases. Recently, oxathiazol-2-one moiety was identified in a high-throughput screening campaign as a promising candidate. ${ }^{21}$ The proposed mechanism of the covalent modification of $N$-terminal threonine induced by this electrophilic fragment is depicted in Figure 2 and proceeds through cyclocarbonylation. ${ }^{18,21}$ In current paper we describe an optimized synthetic approach towards oxathiazol-2-one electrophilic war-

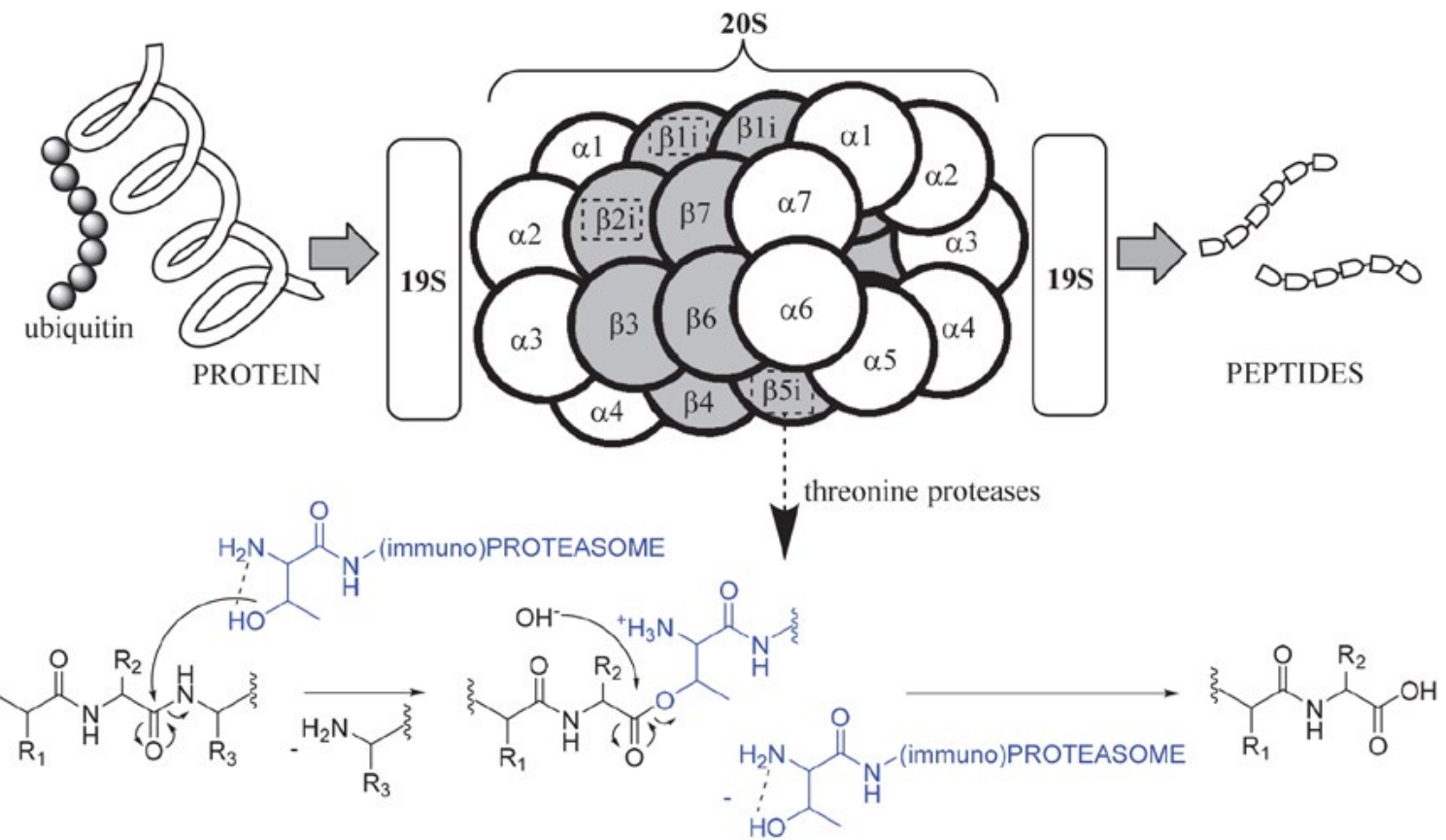

Figure 1. Proteasome (immunoproteasome) assembly with $\beta 1 \mathrm{i}$ (caspase-like), $\beta 2 \mathrm{i}$ (trypsin-like) and $\beta 5 \mathrm{i}$ (chymotrypsin-like) N-terminal threonine proteases. 


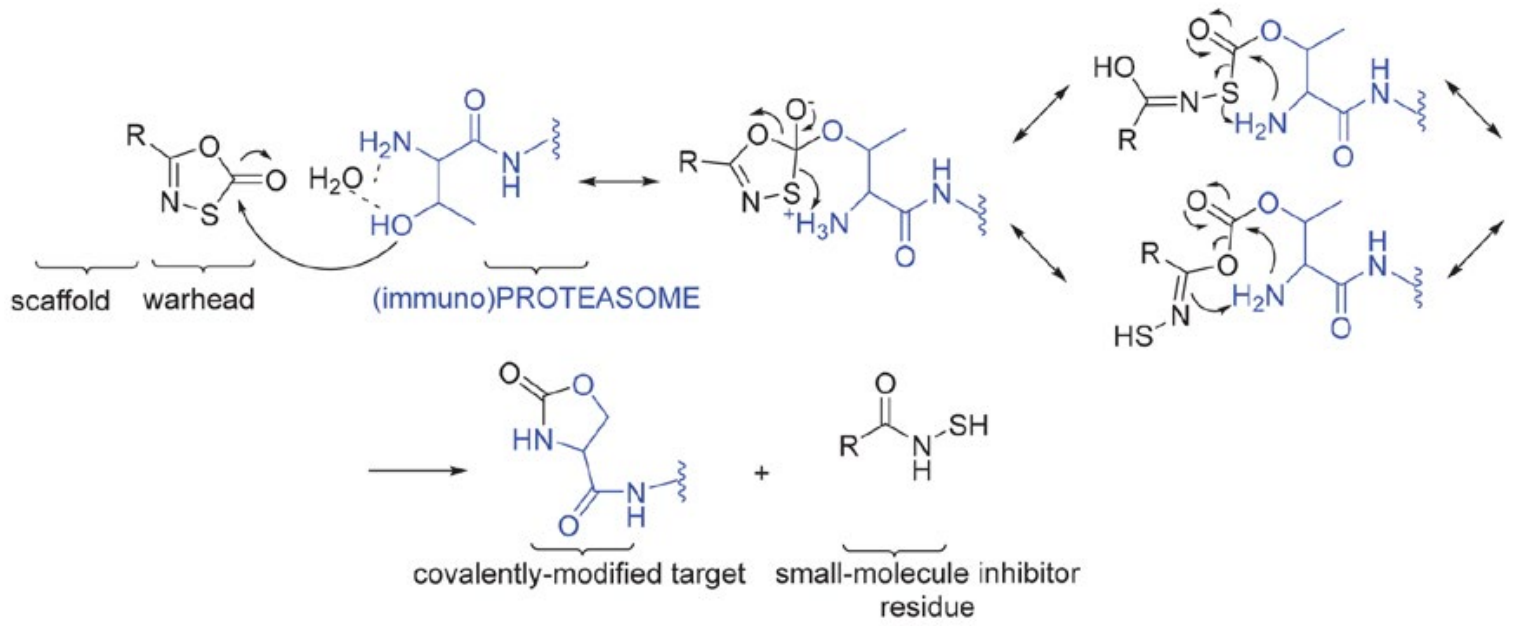

Figure 2. Oxathiazol-2-one electrophilic warhead and its interaction mechanism with the N-terminal threonine in the active site

head in compounds with basic nitrogen atom and the preparation of a focused library of piperidin-3-yl-oxathiazol-2-ones that are suitable for further biological evaluation.

\section{Results and Discussion}

We designed our compounds on the basis of their synthetic accessibility and their potential to be modified accordingly during further optimizations. Therefore, we selected a piperidine central core derivatized with an electrophilic oxathiazol-2-one warhead that could confer the selectivity towards threonine proteases as reported beforehand (Figure 3). ${ }^{18,21}$

We started the synthesis with the alkylation of nipecotamide employing a set of alkyl bromides in DMF as a solvent and $\mathrm{Na}_{2} \mathrm{CO}_{3}$ as a base to obtain compounds $2 \mathbf{a}$, $\mathbf{2 b}$ and $\mathbf{2 c}-\mathbf{e}$. In the case of compound $\mathbf{2 f}$, alkylation with $p$-nitrobenzylbromide was followed by hydrogenation in $\mathrm{MeOH}$ with final acylation using benzyl chloride. The key step in the synthesis was the cyclization of suitably substituted nipecotamides $\mathbf{2 a - f}$ into piperidin-3-yl-oxathiazol2-ones 7-3e using chlorocarbonylsulfenyl chloride as a reagent (Figure 4). This synthetic approach was reported by Gryder et al. when they described the synthesis of the oxathiazol-2-one analogue of bortezomib. The penultimate carboxamide dipeptide was successfully transformed into the oxathiazol-2-one-bortezomib in high yield by using chlorocarbonylsulfenyl chloride in refluxing THF. ${ }^{22}$

Despite our numerous attempts to obtain the final oxathiazol-2-ones $\mathbf{3 a}-\mathbf{f}$ by following the original procedure no product could be isolated. Initial experiments in refluxing THF resulted in a complex mixture of products. ${ }^{23}$ If the experiments were performed at lower temperature $\left(0{ }^{\circ} \mathrm{C}\right.$, room temperature), no apparent conversion was observed. Our first modification of the original procedure was to use relatively nonpolar and system-inert toluene as a solvent that could provide an alternative reactant/intermediate stabilization pattern and would enable a broader temperature sweep. This system was also described by Gurjar et al. where they heated the mixture of amide and chlorocarbonylsulfenyl chloride in toluene from 60 to $90{ }^{\circ} \mathrm{C}$ until the settlement of $\mathrm{HCl}$ evolution, followed by $1 \mathrm{~h}$ of reflux; this yielded $>50 \%$ of isolated oxathiazol-2-one..$^{23}$ No conversion was observed in our case at lower temperatures $\left(0{ }^{\circ} \mathrm{C}\right.$, room temperature) with a formation of complex mixture of products at $60^{\circ} \mathrm{C}$ and reflux conditions. Further experiments using pyridine as solvent afforded similar results. Nevertheless, a difference in reaction scope can be observed as besides previously mentioned report by Gryder et al., ${ }^{22}$ literature only describes a relatively simple case of benzamide cyclization towards final 5-phenyl-1,3,4-oxathiazol-2-one. In our case, the reaction incorporated a piperidin-3-yl central scaffold (compounds 2a-e) containing an additional basic centre. We also conducted a thor-

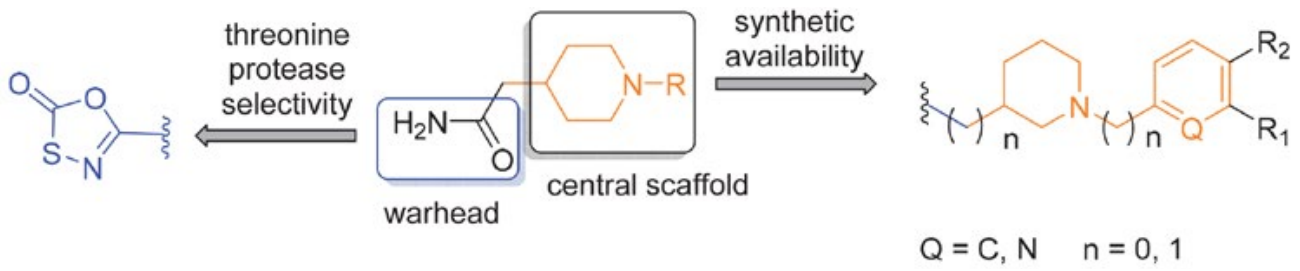

Figure 3. Design of piperidin-3-yl-oxathiazol-2-ones as potential covalent inhibitors of threonine proteases. 


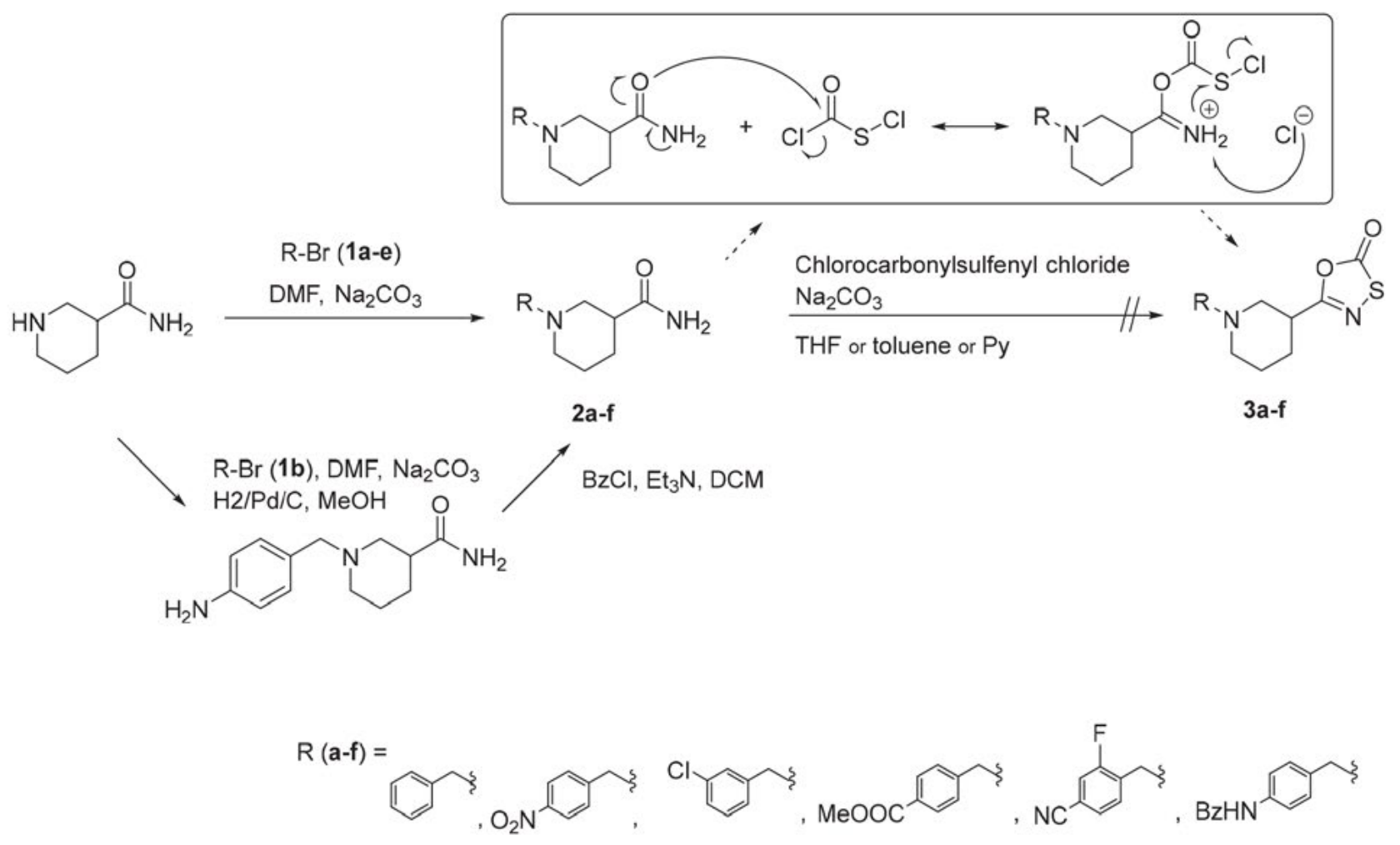

Figure 4. Cyclization of piperidine carboxamides towards final piperidin-3-yl-oxathiazol-2-ones.

ough separation of complex product mixtures in the case of cyclization of compound $\mathbf{2 a}$ and identified a dominant side product ( $>30 \%$ yield) flanked by a myriad of other chemical species that could not be obtained at a significant quantity. The dominant side product was identified when examining its ${ }^{13} \mathrm{C}$ NMR spectrum. Namely, the carbon atom of the carboxamide $2 \mathrm{a}$ can be found as expected at $178.3 \mathrm{ppm}$ (400 MHz, DMSO- $d_{6}$ ), whereas the carbon of the dominant side product species was found upfield at $121.8 \mathrm{ppm}$. When recording IR spectrum, a marked peak at $2240 \mathrm{~cm}^{-1}$ was found indicating the presence of a nitrile functionality; the formation of the side product 1-benzylpiperidine-3-carbonitrile $\mathbf{4 a}$ (Figure 5) was then further confirmed by
HRMS. The nature of this reaction outcome can be rationalized as presented in Figure 5.

In our reaction system, the dehydration process is facilitated by the primary amide $2 \mathrm{a}$ (Figure 5) that readily couples with the chlorocarbonylsulfenyl chloride to form an active intermediate (Figure 5). The coupling is followed by rapid elimination that is catalyzed either with the starting substituted piperidine as a base or is assisted by other bases in the reaction system (such as pyridine) to form the corresponding nitrile $\mathbf{4 a}$ (Figure 5). Indeed, similar dehydrations of primary carboxamides using an acidic reagent such as $\mathrm{POCl}_{3}, \mathrm{SOCl}_{2}$ are well documented in literature. ${ }^{24,25}$ More recent, chemoselective and milder methods were<smiles>[R]N1CCCC(C(N)=O)C1</smiles>

$2 a-b$

$\mathrm{R}=$<smiles>CCc1ccc([N+](=O)[O-])cc1</smiles><smiles>[R]N1CCCC(C(=NCCC([R15])(C)C)OC(=O)SCl)C1</smiles>

THF or toluene or Py<smiles>O=C([O-])SCl</smiles>

BASE $=$<smiles>[R]N1CCCC(C(N)=O)C1</smiles>

Figure 5. The proposed mechanism of dexydration of primary amides to nitriles using chlorocarbonylsulfenyl chloride. 


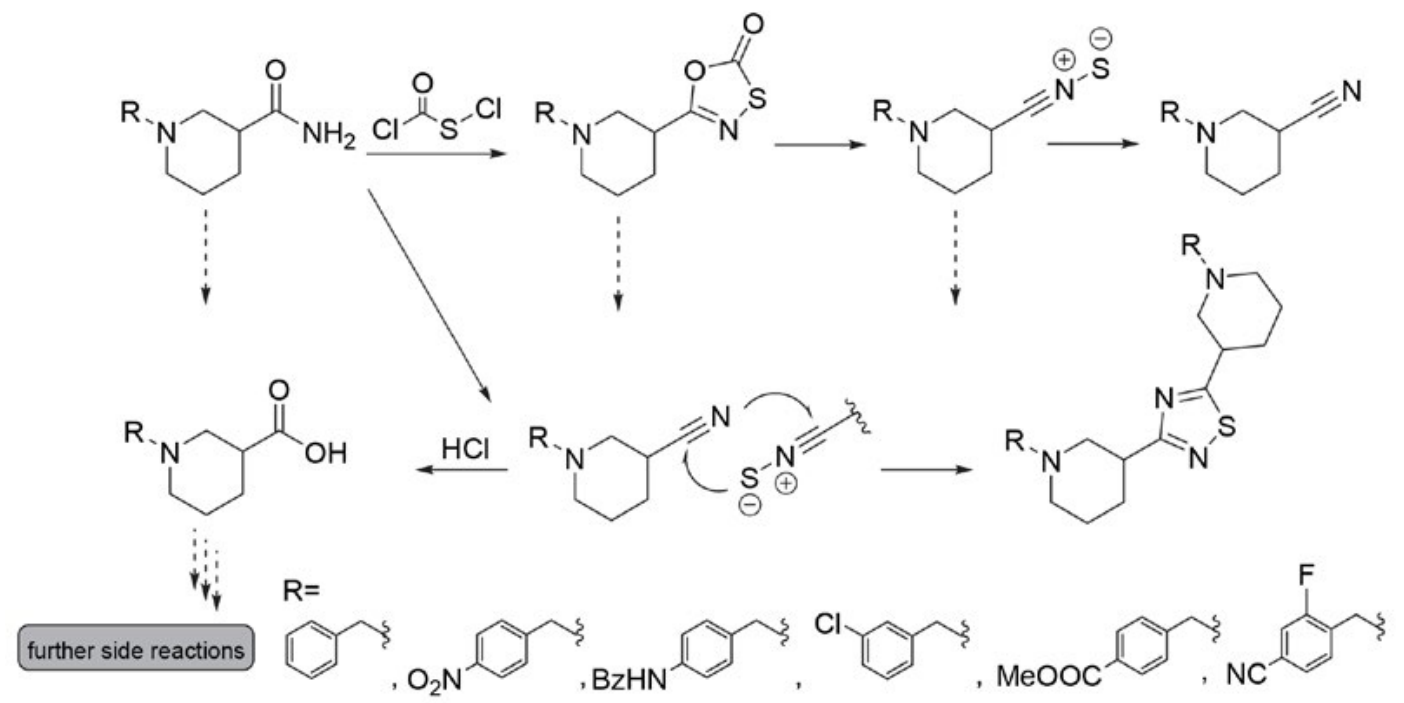

Figure 6. Possible side reaction pathways in the synthesis of piperidin-3-yl-oxathiazol-2-ones.

also reported, where ethyl dichlorophosphate/DBU system or methyl (carboxysulfamoyl)triethylammonium hydroxide (Burgess reagent) were used as the dehydrating reagents. ${ }^{26,27}$ In addition, Vilsmeier reagents, ${ }^{28}$ bromodimethylsulfonium bromide (BDMS) ${ }^{29} \mathrm{PdCl}_{2}$ in aqueous acetonitrile, ${ }^{30}$ Swern oxidation conditions and other catalytic or alternative methods using silanes, silazanes, chlorosilanes, alkoxysilanes, and aminosilanes were also de- scribed. ${ }^{31-33}$ The myriad of reaction side products that was observed is a consequence of multitude of side reactions that can occur during dehydration reactions, such as thermal decomposition of the formed oxathiazol-2-one and hydrolysis reactions (Figure 6). The formed oxathiazol-2-one can also take part in the 1,3-dipolar nitrile sulphide cycloaddition reaction with available nitrile to obtain thiadiazoles as side products. ${ }^{34}$ The nitrile sulphide is

Table 1. Synthesis of piperidin-3-yl-oxathiazol-2-ones 3a-f.

Cpd. No Yield (n) (\%)

${ }^{a}$ Yield after purification using column chromatography $\left(\mathrm{SiO}_{2}\right.$ support with $n$-hexane:EtOAc solvent system as an eluent). 
generated in situ by thermal decomposition of oxathiazol-2-one. ${ }^{35}$ Nitrile sulphides are short-lived species prone to fragmentation and can take part in further cycloadditions. ${ }^{36-38}$

After initial unsuccessful attempts to prepare the desired compounds $\mathbf{3 a}-\mathbf{f}$, we turned our attention to microwave-assisted report on flow-chemistry synthesis of oxathiazol-2-one in dioxane at $200{ }^{\circ} \mathrm{C}$ and residence time of $1 \mathrm{~min}$ in a flow reactor reported by Öhrngren et al. ${ }^{39} \mathrm{On}$ this basis, we modified the reaction procedure and dissolved the carboxamides 2a-f (Figure 4) in dry dioxane $(27 \mathrm{~mL} / 1 \mathrm{mmol}$ carboxamide), used an excess of solid $\mathrm{Na}$ ${ }_{2} \mathrm{CO}_{3}$ (5 eq) and chlorocarbonylsulfenyl chloride (2 eq), and stirred the reaction mixture at $100^{\circ} \mathrm{C}$ for $16 \mathrm{~h}$ under argon to obtain the desired oxathiazol-2-ones 3a-f (Figure 4 ) in 16 to $68 \%$ yields (Table 1 ).

\section{Experimental}

Chemicals from commercial sources were used without further purification. Anhydrous THF, DCM and $\mathrm{Et}_{3} \mathrm{~N}$ were dried and purified by distillation over $\mathrm{Na}$, $\mathrm{K}_{2} \mathrm{CO}_{3}$ and $\mathrm{KOH}$, respectively. Analytical thin-layer chromatography (TLC) was performed on Merck silica gel $\left(60 \mathrm{~F}_{254}\right)$ plates $(0.25 \mathrm{~mm})$. Column chromatography was performed on silica gel 60 (Merck, particle size 0.040$0.063 \mathrm{~mm}$ ). Melting points were determined on a Reichert hot stage microscope and are uncorrected. ${ }^{1} \mathrm{H}-$, COSY-, HMQC- and ${ }^{13} \mathrm{C}-\mathrm{NMR}$ spectra were recorded on a Bruker AVANCE DPX ${ }_{400}$ spectrometer in $\mathrm{CDCl}_{3}$ or DMSO- $d_{6}$ solution with TMS as internal standard. Chemical shifts are reported in ppm $(\delta)$ downfield from TMS. All the coupling constants $(J)$ are in hertz. IR spectra were recorded on a PerkinElmer Spectrum BX System FT-IR spectrometer. Mass spectra were obtained with a VG-Analytical Autospec Q mass spectrometer with ESI ionization (MS Centre, Jožef Stefan Institute, Ljubljana). All reported yields are those of purified products.

\section{1-Benzylpiperidine-3-carboxamide (2a)}

To a solution of piperidine-3-carboxamide (500 $\mathrm{mg}$, $3.90 \mathrm{mmol}$ ) in $50 \mathrm{~mL}$ DMF, solid $\mathrm{Na}_{2} \mathrm{CO}_{3}(460 \mathrm{mg}, 4.33$ $\mathrm{mmol}$ ) and benzyl bromide (1.44 g, $8.42 \mathrm{mmol})$ were added. The reaction was stirred at $100^{\circ} \mathrm{C}$ overnight. DMF was removed under reduced pressure, the residue dissolved in EtOAc $(30 \mathrm{~mL})$ and extracted with $0,5 \mathrm{M} \mathrm{HCl}(2 \times 15 \mathrm{~mL})$. The $\mathrm{pH}$ of combined aqueous phases was adjusted to 8 with $\mathrm{NaHCO}_{3}$ and extracted with EtOAc $(4 \times 30 \mathrm{~mL})$. Combined organic phases were washed with $\mathrm{H}_{2} \mathrm{O}(1 \times 30$ $\mathrm{ml})$, brine $(1 \times 30 \mathrm{~mL})$ and dried over $\mathrm{Na}_{2} \mathrm{SO}_{4}$. The volatiles were removed under reduced pressure to give compound $2 \mathrm{a}$ as white solid. Yield $=56 \%$; TLC (EtOAc: $\mathrm{MeOH}$ $=2: 1), \mathrm{R}_{\mathrm{f}}=0,50 ;$ m.p. $108-110{ }^{\circ} \mathrm{C} ;{ }^{1} \mathrm{H}$ NMR $(400 \mathrm{MHz}$, DMSO-d $d_{6} \delta 1.34-1.48(\mathrm{~m}, 2 \mathrm{H}, \mathrm{H}-5), 1.58-1.74(\mathrm{~m}, 2 \mathrm{H}$, H-4), 1.85-1.99 (m, 2H, H-6), 2.27-2.32 (m, 1H, H-2),
2.68-2.78 (m, 2H, H-2 and $\mathrm{H}-3), 3.44(\mathrm{dd}, J 4.4,13.2 \mathrm{~Hz}$, $\left.2 \mathrm{H}, \mathrm{CH}_{2}\right), 6.75$ (br s, $1 \mathrm{H}, \mathrm{NH}_{2}$ ), 7.22-7.34 (m, 6H, ArH and $\left.\mathrm{NH}_{2}\right) ;{ }^{13} \mathrm{C}$ NMR $\left(400 \mathrm{MHz}, \mathrm{CDCl}_{3}\right) \delta 22.8(\mathrm{C}-5), 26.9$ (C-4), 41.8 (C-3), $53.8(\mathrm{C}-6), 55.0(\mathrm{C}-2), 63.5\left(\mathrm{CH}_{2}\right)$, 127.4 (C-4'), $128.4\left(\mathrm{C}-3^{\prime}\right.$ and $\left.\mathrm{C}-5^{\prime}\right), 129.2\left(\mathrm{C}-2^{\prime}\right.$ and C-6'), $137.6\left(\mathrm{C}-1^{\prime}\right), 178.0\left(\mathrm{OCNH}_{2}\right)$; IR (ATR) v 3333, 3148, 2932, 2758, 1632, 1429, 1368, 1356, 1337, 1253, 1100, $1070,1002,858,734,698,666,564,518 \mathrm{~cm}^{-1}$; MS m/z (relative intensity): $240.95(\mathrm{M}+\mathrm{Na}, 100), 219.03(\mathrm{M}+\mathrm{H}, 30)$.

\section{1-(4-Nitrobenzyl)piperidine-3-carboxamide (2b)}

To a solution of piperidine-3-carboxamide $(500 \mathrm{mg}$, $3.90 \mathrm{mmol}$ ) in $50 \mathrm{~mL}$ DMF, solid $\mathrm{Na}_{2} \mathrm{CO}_{3}(460 \mathrm{mg}, 4.33$ $\mathrm{mmol}$ ) and 4-nitrobenzyl bromide $(1.69 \mathrm{~g}, 7.82 \mathrm{mmol})$ were added. The reaction was stirred at $100{ }^{\circ} \mathrm{C}$ overnight. DMF was removed under reduced pressure, the residue dissolved in EtOAc $(30 \mathrm{~mL})$ and extracted with $0.5 \mathrm{M} \mathrm{HCl}$ $(2 \times 15 \mathrm{~mL})$. The $\mathrm{pH}$ of combined aqueous phases was adjusted to 8 with $\mathrm{NaHCO}_{3}$ and extracted with EtOAc $(4 \times 30$ $\mathrm{mL})$. Combined organic phases were washed with $\mathrm{H}_{2} \mathrm{O}(1$ $\times 30 \mathrm{ml})$, brine $(1 \times 30 \mathrm{~mL})$ and dried over $\mathrm{Na}_{2} \mathrm{SO}_{4}$. The volatiles were removed under reduced pressure to give compound $\mathbf{2 b}$ as pale orange solid. Yield $=93 \%$; TLC (EtOAc: $\mathrm{MeOH}=2: 1$ ), $\mathrm{R}_{\mathrm{f}}=0.63$; m.p. $111-114{ }^{\circ} \mathrm{C} ;{ }^{1} \mathrm{H}$ NMR (400 MHz, DMSO- $\left.d_{6}\right) \delta 1.33-1.36(\mathrm{~m}, 1 \mathrm{H}, \mathrm{H}-5)$, $1.43-1.48(\mathrm{~m}, 1 \mathrm{H}, \mathrm{H}-4), 1.60-1.65(\mathrm{~m}, 1 \mathrm{H}, \mathrm{H}-5), 1.72-$ $1.76(\mathrm{~m}, 1 \mathrm{H}, \mathrm{H}-4), 1.91-2.09(\mathrm{~m}, 2 \mathrm{H}, \mathrm{H}-6$ and $\mathrm{H}-2)$, 2.30-2.33 (m, 1H, H-6), 2.69-2.78 ( $\mathrm{m}, 2 \mathrm{H}, \mathrm{H}-2$ and $\mathrm{H}-3)$, 3.55-3.63 (m, 2H, $\left.\mathrm{CH}_{2}\right), 6.76\left(\mathrm{br} \mathrm{s}, 1 \mathrm{H}, \mathrm{NH}_{2}\right), 7.27$ (br s, $\left.1 \mathrm{H}, \mathrm{NH}_{2}\right), 7.56-7.60\left(\mathrm{~m}, 2 \mathrm{H}, \mathrm{H}-2^{\prime}\right.$ and $\left.\mathrm{H}-6^{\prime}\right), 8.19$ (dd, $J$ 2.0, $4.8 \mathrm{~Hz}, 2 \mathrm{H}, \mathrm{H}-3^{\prime}$ and $\left.\mathrm{H}-5^{\prime}\right) ;{ }^{13} \mathrm{C}$ NMR $(400 \mathrm{MHz}$, DMSO-d $\left.{ }_{6}\right) \delta 24.4(\mathrm{C}-5), 27.0(\mathrm{C}-4), 42.3(\mathrm{C}-3), 53.2$ (C-6), $55.8(\mathrm{C}-2), 61.4\left(\mathrm{CH}_{2}\right), 123.3\left(\mathrm{C}-3^{\prime}\right.$ and $\left.\mathrm{C}-5^{\prime}\right)$, 129.6 (C-2' and C-6'), 146.5 (C-1'), 146.9 (C-4'), 175.4 $\left(\mathrm{OCNH}_{2}\right)$; IR (ATR) v 3385, 3180, 2926, 2787, 1644, 1605, 1512, 1421, 1341, 1249, 1204, 1166, 1102, 1048, 989, 862, 797, 736,720 $\mathrm{cm}^{-1} ;$ MS $\mathrm{m} / z$ (relative intensity): 261.97 $(\mathrm{M}-\mathrm{H}, 100)$.

\section{1-(4-Chlorobenzyl)piperidine-3-carboxamide (2c)}

To a solution of piperidine-3-carboxamide $(500 \mathrm{mg}$, $3.90 \mathrm{mmol}$ ) in $50 \mathrm{~mL}$ DMF, solid $\mathrm{Na}_{2} \mathrm{CO}_{3}(460 \mathrm{mg}$, 4.33 $\mathrm{mmol}$ ) and 3-chlorobenzyl bromide $(1.64 \mathrm{~g}, 7.99 \mathrm{mmol})$ were added. The reaction was stirred at $100{ }^{\circ} \mathrm{C}$ overnight. DMF was removed under reduced pressure, the residue dissolved in EtOAc $(30 \mathrm{~mL})$ and extracted with $0.5 \mathrm{M} \mathrm{HCl}$ $(2 \times 15 \mathrm{~mL})$. The $\mathrm{pH}$ of combined aqueous phases was adjusted to 8 with $\mathrm{NaHCO}_{3}$ and extracted with EtOAc $(4 \times 30$ $\mathrm{mL})$. Combined organic phases were washed with $\mathrm{H}_{2} \mathrm{O}(1$ $\times 30 \mathrm{ml})$, brine $(1 \times 30 \mathrm{~mL})$ and dried over $\mathrm{Na}_{2} \mathrm{SO}_{4}$. The volatiles were removed under reduced pressure to give compound $2 \mathrm{c}$ as pale orange solid. Yield $=53 \%$; TLC (EtOAc: $\mathrm{MeOH}=2: 1), \mathrm{R}_{\mathrm{f}}=0.60 ;{ }^{1} \mathrm{H}$ NMR $(400 \mathrm{MHz}$, $\left.\mathrm{CDCl}_{3}\right) \delta 1.55-1.61(\mathrm{~m}, 1 \mathrm{H}, \mathrm{H}-5), 1.65-1.77(\mathrm{~m}, 2 \mathrm{H}, \mathrm{H}-4$ and $\mathrm{H}-5), 1.82-1.84(\mathrm{~m}, 1 \mathrm{H}, \mathrm{H}-4), 2.26(\mathrm{~s}, 1 \mathrm{H}, \mathrm{H}-6)$, 2.44-2.53 (m, 2H, H-2 and H-6), 2.59 (s, 1H, H-2), 2.73

Jukič et al.: Chlorocarbonylsulfenyl Chloride Cyclizations ... 
(s, 1H, H-3), 3.46 (s, 2H, $\mathrm{CH}_{2}$ ), 6.07 (br s, 1H, $\mathrm{NH}_{2}$ ), 7.14$7.16\left(\mathrm{~m}, 1 \mathrm{H}, \mathrm{NH}_{2}\right), 7.24-7.26(\mathrm{~m}, 4 \mathrm{H}, \mathrm{ArH}) ;{ }^{13} \mathrm{C} \mathrm{NMR}(400$ $\mathrm{MHz}, \mathrm{CDCl}_{3}$ ) $\delta 22.9$ (C-5), 26.9 (C-4), 41.9 (C-3), 53.7 (C-6), 55.1 (C-2), $62.9\left(\mathrm{CH}_{2}\right), 127.2,127.6\left(\mathrm{C}-3^{\prime}\right.$ and C-5'), 129.1, 129.7 (C-2' and C-6'), 134.3 (C-4'), 139.8 $\left(\mathrm{C}-1^{\prime}\right), 177.8\left(\mathrm{CONH}_{2}\right)$; IR (ATR) v 3342, 3162, 2937, 2800, 2763, 1626, 1597, 1573, 1426, 1371, 1342, 1300, 1256, $1207,1157,1106,1075,1044,996,985,930,892,875,863$, $808,786,776,717,682,655,569,516 \mathrm{~cm}^{-1}$; MS m/z (relative intensity): $275.29(\mathrm{M}+\mathrm{Na}, 100), 253.29(\mathrm{M}+\mathrm{H}, 20)$.

\section{Methyl 4-((3-carbamoylpiperidin-1-yl)methyl)benzo- ate (2d)}

To a solution of piperidine-3-carboxamide $(200 \mathrm{mg}$, $1.56 \mathrm{mmol}$ ) in $50 \mathrm{~mL}$ DMF, solid $\mathrm{Na}_{2} \mathrm{CO}_{3}(320 \mathrm{mg}, 3.02$ $\mathrm{mmol}$ ) and methyl 4-(bromomethyl)benzoate $(540 \mathrm{mg}$, $2.36 \mathrm{mmol}$ ) were added. The reaction was stirred at $100^{\circ} \mathrm{C}$ overnight. DMF was removed under reduced pressure, the residue dissolved in EtOAc $(30 \mathrm{~mL})$ and extracted with 0.5 $\mathrm{M} \mathrm{HCl}(2 \times 15 \mathrm{~mL})$. The $\mathrm{pH}$ of combined aqueous phases was adjusted to 8 with $\mathrm{NaHCO}_{3}$ and extracted with EtOAc $(4 \times 30 \mathrm{~mL})$. Combined organic phases were washed with $\mathrm{H}_{2} \mathrm{O}(1 \times 30 \mathrm{ml})$, brine $(1 \times 30 \mathrm{~mL})$ and dried over $\mathrm{Na}_{2} \mathrm{SO}_{4}$. The volatiles were removed under reduced pressure to give compound $\mathbf{2 d}$ as white solid. Yield $=91 \%$; TLC (EtOAc: $\mathrm{MeOH}=2: 1), \mathrm{R}_{\mathrm{f}}=0.62 ;{ }^{1} \mathrm{H} \mathrm{NMR}(400 \mathrm{MHz}$, DMSO-d $) \delta 1.32-1.42(\mathrm{~m}, 1 \mathrm{H}, \mathrm{H}-5), 1.44-1.49(\mathrm{~m}, 1 \mathrm{H}$, $\mathrm{H}-4), 1.59-1.64$ (m, 1H, H-5), 1.71-1.75 (m, 1H, H-4), 1.88-1.95 (m, 1H, H-6), 1.98-2.03 (m, 1H, H-2), 2.292.35 (m, 1H, H-6), 2.68-2.71 (m, 1H, H-2), 2.74-2.78 (m, $1 \mathrm{H}, \mathrm{H}-3), 3.52$ (d, J $\left.2.8 \mathrm{~Hz}, 2 \mathrm{H}, \mathrm{CH}_{2}\right), 3.85$ (s, 3H, $\mathrm{CH}_{3}$ ), 6.77 (br s, $1 \mathrm{H}, \mathrm{NH}_{2}$ ), 7.27 (br s, $1 \mathrm{H}, \mathrm{NH}_{2}$ ), 7.44 (d, J $8.4 \mathrm{~Hz}$, 2H, H-2' and H-6'), 7.92 (dd, J 2.0, $4.8 \mathrm{~Hz}, 2 \mathrm{H}, \mathrm{H}-3^{\prime}$ and H-5'); IR (ATR) v 3403, 3183, 2936, 2797, 1715, 1647, 1434, 1415, 1273, 1239, 1199, 1165, 1112,1086, 1027, 995, $964,860,806,760,754,706 \mathrm{~cm}^{-1}$.

\section{1-(4-Cyano-2-fluorobenzyl)piperidine-3-carboxamide} (2e)

To a solution of piperidine-3-carboxamide $(500 \mathrm{mg}$, $3.90 \mathrm{mmol}$ ) in $50 \mathrm{~mL} \mathrm{DMF}$, solid $\mathrm{Na}_{2} \mathrm{CO}_{3}$ (460 mg, 4.33 $\mathrm{mmol}$ ) and 4-(bromomethyl)-3-fluorobenzonitrile (1.75 $\mathrm{g}, 8.17 \mathrm{mmol}$ ) were added. The reaction was stirred at 100 ${ }^{\circ} \mathrm{C}$ overnight. DMF was removed under reduced pressure, the residue dissolved in EtOAc $(30 \mathrm{~mL})$ and extracted with $0.5 \mathrm{M} \mathrm{HCl}(2 \times 15 \mathrm{~mL})$. The $\mathrm{pH}$ of combined aqueous phases was adjusted to 8 with $\mathrm{NaHCO}_{3}$ and extracted with EtOAc $(4 \times 30 \mathrm{~mL})$. Combined organic phases were washed with $\mathrm{H}_{2} \mathrm{O}(1 \times 30 \mathrm{ml})$, brine $(1 \times 30 \mathrm{~mL})$ and dried over $\mathrm{Na}_{2} \mathrm{SO}_{4}$. The volatiles were removed under reduced pressure to give compound $\mathbf{2 e}$ as pale yellow solid. Yield = $71 \%$; TLC (EtOAc:MeOH = 2:1), $\mathrm{R}_{\mathrm{f}}=0.66$; m.p. 126-128 ${ }^{\circ} \mathrm{C}$; ${ }^{1} \mathrm{H}$ NMR (400 MHz, DMSO-d $) \delta 1.30-1.31(\mathrm{~m}, 1 \mathrm{H}$, $\mathrm{H}-5), 1.42-1.45$ (m, 1H, H-4), 1.59-1.64 (m, 1H, H-5), 1.69-1.73 (m, 1H, H-4), 1.93-1.99 (m, 1H, H-6), 2.02$2.08(\mathrm{~m}, 1 \mathrm{H}, \mathrm{H}-2), 2.28-2.33(\mathrm{~m}, 1 \mathrm{H}, \mathrm{H}-6), 2.67-2.70(\mathrm{~m}$,
1H, H-2), 2.74-2.78 (m, 1H, H-3), 3.58 (s, 2H, $\mathrm{CH}_{2}$ ), 6.77 (br s, $1 \mathrm{H}, \mathrm{NH}_{2}$ ), 7.27 (br s, $1 \mathrm{H}, \mathrm{NH}_{2}$ ), $7.61(\mathrm{t}, J 7.6 \mathrm{~Hz}, 1 \mathrm{H}$, H-5'), 7.68 (dd, J 1.6, 6.4 Hz, 1H, H-2'), 7.82 (dd, J 1.6, 8.4 $\mathrm{Hz}, 1 \mathrm{H}, \mathrm{H}-3$ '); ${ }^{13} \mathrm{C}$ NMR $\left(400 \mathrm{MHz}, \mathrm{CDCl}_{3}\right) \delta 22.9(\mathrm{C}-5)$, 26.8 (C-4), $41.9(\mathrm{C}-3), 53.5(\mathrm{C}-6), 55.3(\mathrm{C}-2), 56.0\left(\mathrm{CH}_{2}\right)$, 112.8(C-4'), $117.5(\mathrm{CN}), 119.2\left(\mathrm{C}-5^{\prime}\right), 128.1$ (C-3'), 130.8 (C-1'), 132.3 (C-2'), 162.1 (C-6'), $177.5\left(\mathrm{OCNH}_{2}\right)$; IR $(\mathrm{ATR}) \vee 3364,3187,2929,2811,2227,1646,1611,1569$, 1486, 1411, 1350, 1298, 1246, 1201, 1166, 1089, 1002, 941, $849,830,731 \mathrm{~cm}^{-1} ;$ MS $\mathrm{m} / z$ (relative intensity): 283.71 $(\mathrm{M}+\mathrm{Na}, 100), 261.78(\mathrm{M}+\mathrm{H}, 20)$.

\section{1-(4-Benzamidobenzyl)piperidine-3-carboxamide (2f)} Argon was bubbled into a solution of $\mathbf{2 b}(5.811 \mathrm{~g}$, $17.6 \mathrm{mmol})$ in $\mathrm{MeOH}(70 \mathrm{~mL})$ for 15 minutes. $10 \% \mathrm{Pd} / \mathrm{C}$, unreduced, was then added and $\mathrm{H}_{2}$ was bubbled into the stirred solution until the starting compound was no longer observed with TLC. Pd/C was filtered off and the solution concentrated in vacuo to yield crude product which was purified with column cromatography (EtOAc: $\mathrm{MeOH}=$ 2:1). Oily product was dissolved in DCM (30 mL). Et ${ }_{3} \mathrm{~N}$ (250 mg, $2.47 \mathrm{mmol}$ ) and benzoyl chloride (265 mg, 2.36 $\mathrm{mmol}$ ) were added and the reaction mixture was stirred at room temperature overnight. DCM was removed under reduced pressure, the residue dissolved in EtOAc $(30 \mathrm{~mL})$ and extracted with $0.5 \mathrm{M} \mathrm{HCl}(1 \times 10 \mathrm{~mL})$. The $\mathrm{pH}$ of combined aqueous phases was adjusted to 8 with $\mathrm{NaHCO}_{3}$ and extracted with EtOAc $(2 \times 15 \mathrm{~mL})$. Combined organic phases were washed with $\mathrm{H}_{2} \mathrm{O}(1 \times 20 \mathrm{ml})$, brine $(1 \times 20$ $\mathrm{mL})$ and dried over $\mathrm{Na}_{2} \mathrm{SO}_{4}$. The volatiles were removed under reduced pressure to give compound $\mathbf{2} \mathbf{f}$ as colourless oil. Yield = $16 \%$; TLC (EtOAc: $\mathrm{MeOH}=2: 1), \mathrm{R}_{\mathrm{f}}=0.36 ;{ }^{1} \mathrm{H}$ NMR (400 MHz, DMSO-d $)$ d 1.06-1.63 (m, 1H, H-5), 1.64-1.70 (m, 3H, H-4 and H-5), 1.89-1.99 (m, $1 \mathrm{H}, \mathrm{H}-6)$, 2.29-2.34 (m, 2H, H-2 and H-6), 2.67-2.76 (m, 1H, H-2), 2.78-2.99 (m, 1H, H-3), 3.01-3.51(m, 2H, $\left.\mathrm{CH}_{2}\right), 6.76$ (br s, $\left.1 \mathrm{H}, \mathrm{NH}_{2}\right), 7.24-7.29$ (m, 3H, H-2' and $\mathrm{H}-6$ ' and $\mathrm{NH}_{2}$ ), 7.52-7.62 (m, 3H, H-3"and H-4"and H-5"), 7.72-7.7 6 (m, 2H, H-3' and $\mathrm{H}-5$ '), 7.95-7.97 (m, 2H, H-2" and H-6”), 10.26 (d, J $4.4 \mathrm{~Hz}, 1 \mathrm{H}, \mathrm{NH}$ ).

\section{5-(1-Benzylpiperidin-3-yl)-1,3,4-oxathiazol-2-one (3a)}

To a solution of 1-benzylpiperidine-3-carboxamide (2a, $240 \mathrm{mg}, 1.10 \mathrm{mmol})$ in dioxane $(30 \mathrm{~mL})$ in a threenecked flask, solid $\mathrm{Na}_{2} \mathrm{CO}_{3}(580 \mathrm{mg}, 5.47 \mathrm{mmol}$ ) and chlorocarbonylsulfenyl chloride $(288 \mathrm{mg}, 2.20 \mathrm{mmol})$ were added under argon. The reaction mixture was stirred at $100{ }^{\circ} \mathrm{C}$ overnight, cooled to room temperature and after the addition of $\mathrm{Et}_{3} \mathrm{~N}(0.75 \mathrm{~mL})$ stirred for 15 minutes. The precipitate was filtered off and the residue concentrated in vacuo. Product was purified with column chromatography using hexane:EtOAc=3:1 as an eluent to give yellow oily product. Yield $=68 \%$; TLC (hexane:EtOAc $=3: 1), \mathrm{R}_{\mathrm{f}}=$ $0.56 ;{ }^{1} \mathrm{H}$ NMR (400 MHz, DMSO- $\left.d_{6}\right) \delta 1.50-1.56(\mathrm{~m}, 2 \mathrm{H}$, $\mathrm{H}-5$ and $\mathrm{H}-4), 1.70-1.72(\mathrm{~m}, 1 \mathrm{H}, \mathrm{H}-5), 1.88-1.93(\mathrm{~m}, 1 \mathrm{H}$, $\mathrm{H}-4$ ), 2.08-2.12 (m, 1H, H-6), 2.20-2.25 (m, 1H, H-2),

Jukič et al.: Chlorocarbonylsulfenyl Chloride Cyclizations ... 
2.65-2.68 (m, 1H, H-6), 2.88-2.92 ( $\mathrm{m}, 2 \mathrm{H}, \mathrm{H}-2$ and $\mathrm{H}-3)$, 3.50 (d, J $2.8 \mathrm{~Hz}, 2 \mathrm{H}, \mathrm{CH}_{2}$ ), 7.23-7.34 (m, 5H, ArH); ${ }^{13} \mathrm{C}$ NMR (400 MHz, $\left.\mathrm{CDCl}_{3}\right) \delta 24.2$ (C-5), 27.0 (C-4), 38.6 (C-3), 53.5 (C-6), 55.1 (C-2), $63.1\left(\mathrm{CH}_{2}\right), 127.2(\mathrm{C}-4$ '), 128.3 (C-3' and C-5'), 128.9 (C-2' and C-6'), 137.8 (C1'), 162.9 (NCO), 174.3 (SCO); IR (ATR) v 2942, 2800, 1758, 1666, 1599, 1493, 1467, 1450, 1350, 1320, 1287, 1188, 1152, 1097, 1071, 1049, 1025, 981, 926, 879, 791, 769, 738, 697, 664, 633, 599, 569, $522 \mathrm{~cm}^{-1}$; HRMS-ESI $(\mathrm{m} / z)$ : $[\mathrm{M}+\mathrm{H}]^{+}$calcd for $\mathrm{C}_{14} \mathrm{H}_{16} \mathrm{~N}_{2} \mathrm{O}_{2} \mathrm{~S}, 277.1015$, found, 277.1011.

\section{5-(1-(4-Nitrobenzyl)piperidin-3-yl)-1,3,4-oxathiazol-2-} one (3b)

To a solution of 1-(4-nitrobenzyl)piperidine-3-carboxamide $(\mathbf{2 b}, 100 \mathrm{mg}, 0.380 \mathrm{mmol})$ in dioxane $(20 \mathrm{~mL})$ in a three-necked flask, solid $\mathrm{Na}_{2} \mathrm{CO}_{3}(200 \mathrm{mg}, 1.87 \mathrm{mmol})$ and chlorocarbonylsulfenyl chloride (100 mg, 0.760 $\mathrm{mmol}$ ) were added under argon. The reaction mixture was stirred at $100{ }^{\circ} \mathrm{C}$ overnight, cooled to room temperature and after the addition of $\mathrm{Et}_{3} \mathrm{~N}(0.27 \mathrm{~mL})$ stirred for $15 \mathrm{~min}$ utes. The precipitate was filtered off and the residue concentrated in vacuo. Product was purified with column chromatography using hexane:EtOAc $=2: 1$ as an eluent to give yellow oily product. Yield $=22 \%$; TLC (hexane:EtOAc $=2: 1), \mathrm{R}_{\mathrm{f}}=0.38 ;{ }^{1} \mathrm{H}$ NMR $\left(400 \mathrm{MHz}, \mathrm{DMSO}-d_{6}\right) \delta 1.52-$ $1.58(\mathrm{~m}, 2 \mathrm{H}, \mathrm{H}-4$ and $\mathrm{H}-5), 1.71-1.74(\mathrm{~m}, 1 \mathrm{H}, \mathrm{H}-5)$, 1.91-1.94 (1H, H-4), $2.16(\mathrm{~s}, 1 \mathrm{H}, \mathrm{H}-6), 2.26(\mathrm{~d}, J 9.6 \mathrm{~Hz}$, $\mathrm{H}-2), 2.65-2.68(\mathrm{~m}, 1 \mathrm{H}, \mathrm{H}-6), 2.88-2.96(\mathrm{~m}, 2 \mathrm{H}, \mathrm{H}-2$ and $\mathrm{H}-3), 3.65$ (s, $\left.2 \mathrm{H}, \mathrm{CH}_{2}\right), 7.58\left(\mathrm{~d}, J 8.8 \mathrm{~Hz}, 2 \mathrm{H}, \mathrm{H}-3^{\prime}\right.$ and $\mathrm{H}-5$ '), 8.18 (d, $J 8.8 \mathrm{~Hz}, 2 \mathrm{H}, \mathrm{H}-2$ ' and $\mathrm{H}-6$ '); ${ }^{13} \mathrm{C} \mathrm{NMR}$ $\left(400 \mathrm{MHz}, \mathrm{DMSO}-d_{6}\right) \delta 24.1(\mathrm{C}-5), 26.6(\mathrm{C}-4), 38.3$ $(\mathrm{C}-3), 53.5(\mathrm{C}-6), 54.9(\mathrm{C}-2), 61.5\left(\mathrm{CH}_{2}\right), 123.8(\mathrm{C}-2$ ' and

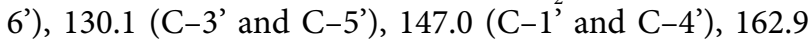
(NCO), 174.7 (SCO); IR (ATR) v 2939, 2792, 1758, 1598, 1515, 1340, 1191, 1092, 926, 858, 802, 738, 650, $571 \mathrm{~cm}^{-1}$; HRMS-ESI $(m / z):[\mathrm{M}+\mathrm{H}]^{+}$calcd for $\mathrm{C}_{14} \mathrm{H}_{15} \mathrm{~N}_{3} \mathrm{O}_{4} \mathrm{~S}$, 322.0867 , found, 322.0862 .

\section{5-(1-(4-Chlorobenzyl)piperidin-3-yl)-1,3,4-oxathiazol- 2-one (3c)}

To a solution of 1-(4-chlorobenzyl)piperidine-3-carboxamide (2c, $300 \mathrm{mg}, 1.19 \mathrm{mmol})$ in dioxane $(30 \mathrm{~mL})$ in a three-necked flask, solid $\mathrm{Na}_{2} \mathrm{CO}_{3}(630 \mathrm{mg}, 5.94 \mathrm{mmol})$ and chlorocarbonylsulfenyl chloride (466 mg, $3.55 \mathrm{mmol}$ ) were added under argon. The reaction mixture was stirred at $100{ }^{\circ} \mathrm{C}$ overnight, cooled to room temperature and after the addition of $\mathrm{Et}_{3} \mathrm{~N}(0.83 \mathrm{~mL})$ stirred for 15 minutes. The precipitate was filtered off and the residue concentrated in vacuo. Product was purified with column chromatography using hexane:EtOAc $=3: 1$ as an eluent to give brown oily product. Yield $=33 \%$; TLC $(\mathrm{H}:$ EtOAc $=3: 1), \mathrm{R}_{\mathrm{f}}=0.42 ;{ }^{1} \mathrm{H}$ NMR $\left(400 \mathrm{MHz}, \mathrm{CDCl}_{3}\right) \delta 1.57-1.69(\mathrm{~m}, 2 \mathrm{H}, \mathrm{H}-5$ and $\mathrm{H}-4), 1.77-1.83(\mathrm{~m}, 1 \mathrm{H}, \mathrm{H}-5), 2.01-2.04(\mathrm{~m}, 1 \mathrm{H}, \mathrm{H}-4)$, 2.09-2.14 (m, H, H-6), 2.28-2.33 (m, 1H, H-2), 2.73-2.76 (m, 1H, H-6), 2.89-2.98 (m, 2H, H-2 and $\mathrm{H}-3), 3.50$ (s, $\left.2 \mathrm{H}, \mathrm{CH}_{2}\right), 7.16-7.31$ (m, $\left.4 \mathrm{H}, \mathrm{ArH}\right) ;{ }^{13} \mathrm{C}$ NMR $(400 \mathrm{MHz}$,
$\left.\mathrm{CDCl}_{3}\right) \delta 24.2(\mathrm{C}-5), 26.9(\mathrm{C}-4), 38.6(\mathrm{C}-3), 53.5(\mathrm{C}-6)$, $55.1(\mathrm{C}-2), 62.5\left(\mathrm{CH}_{2}\right), 126.9,127.4\left(\mathrm{C}-3^{\prime}\right.$ and $\left.\mathrm{C}-5^{\prime}\right)$, 128.9, 128.6 (C-2' and $\left.\mathrm{C}-6^{\prime}\right), 134.2\left(\mathrm{C}-4^{\prime}\right), 140.2\left(\mathrm{C}-1^{\prime}\right)$, 162.7 (NCO), 174.3 (SCO); IR (ATR) v 3339, 3160, 2938, 2801, 2764, 1762, 1626, 1598, 1573, 1463, 1427, 1371, 1342, $1300,1257,1207,1157,1105,1075,1046,997,930,892$, $876,863,808,776,717,705,682,655,569,536,516 \mathrm{~cm}^{-1}$; HRMS-ESI $(m / z):[\mathrm{M}+\mathrm{H}]^{+}$calcd for $\mathrm{C}_{14} \mathrm{H}_{15} \mathrm{ClN}_{2} \mathrm{O}_{2} \mathrm{~S}$, 311.0626, found, 311.0621 .

\section{Methyl 4-((3-(2-oxo-1,3,4-oxathiazol-5-yl)piperidin-1-yl) methyl)benzoate (3d)}

To a solution of methyl 4-((3-carbamoylpiperidin-1-yl)methyl)benzoate (2d, $300 \mathrm{mg}, 1.09 \mathrm{mmol})$ in dioxane $(30 \mathrm{~mL})$ in a three-necked flask, solid $\mathrm{Na}_{2} \mathrm{CO}_{3}(570$ $\mathrm{mg}, 5.38 \mathrm{mmol}$ ) and chlorocarbonylsulfenyl chloride (285 $\mathrm{mg}, 2.16 \mathrm{mmol}$ ) were added under argon. The reaction mixture was stirred at $100{ }^{\circ} \mathrm{C}$ overnight, cooled to room temperature and after the addition of $\mathrm{Et}_{3} \mathrm{~N}(0.75 \mathrm{~mL})$ stirred for 15 minutes. The precipitate was filtered off and the residue concentrated in vacuo. Product was purified with column chromatography using hexane:EtOAc $=2: 1$ as an eluent to give yellow oily product. Yield $=43 \%$; TLC (hexane:EtOAc $=2: 1), \mathrm{R}_{\mathrm{f}}=0.29 ;{ }^{1} \mathrm{H}$ NMR $(400 \mathrm{MHz}$, DMSO- $\left.d_{6}\right) \delta 1.45-1.57(\mathrm{~m}, 2 \mathrm{H}, \mathrm{H}-5, \mathrm{H}-4), 1.72-1.75(\mathrm{~m}$, $1 \mathrm{H}, \mathrm{H}-5), 1.91-1.95(\mathrm{~m}, 1 \mathrm{H}, \mathrm{H}-4), 2.09-2.17(\mathrm{~m}, 1 \mathrm{H}$, $\mathrm{H}-6), 2.24-2.34$ (m, 1H, H-2), 2.65-2.68 (m, 1H, H-6), 2.87-2.96 (m, $2 \mathrm{H}, \mathrm{H}-2$ and $\mathrm{H}-3), 3.59\left(\mathrm{~s}, 2 \mathrm{H}, \mathrm{CH}_{2}\right), 3.85$ (s, $\left.3 \mathrm{H}, \mathrm{CH}_{3}\right), 7.45$ (d, $J 8.4 \mathrm{~Hz}, 2 \mathrm{H}, \mathrm{H}-2^{\prime}$ and $\left.\mathrm{H}^{\prime} 6^{\prime}\right), 7.93$ (dd, J 2.0, 4.8 Hz, 2H, H-3' and $\mathrm{H}-5$ '); ${ }^{13} \mathrm{C}$ NMR (400 $\left.\mathrm{MHz}, \mathrm{DMSO}-d_{6}\right) \delta 23.5(\mathrm{C}-5), 26.1(\mathrm{C}-4), 37.5\left(\mathrm{CH}_{2}\right)$, $52.0(\mathrm{C}-6), 53.0(\mathrm{C}-2), 54.5\left(\mathrm{CH}_{3}\right), 61.5\left(\mathrm{CH}_{2}\right), 128.3$, 128.7, 128.8, 129.1, 129.1 (C-2,3',4,5',6'), 144.0 (C-1'), 162.4 (CO), 166.1 (NCO), 174.2 (SCO); IR (ATR) v 2946, 2801, 1759, 1717, 1609, 1434, 1415, 1395, 1349, 1309, 1275, 1190, 1173, 1106, 1049, 980, 928, 885, 801, 758, 731, 701, 650, 572, $538 \mathrm{~cm}^{-1}$; HRMS-ESI $(\mathrm{m} / z):[\mathrm{M}+\mathrm{H}]^{+}$calcd for $\mathrm{C}_{16} \mathrm{H}_{18} \mathrm{~N}_{2} \mathrm{O}_{4} \mathrm{~S}, 335.1061$, found, 335.1066.

\section{3-Fluoro-4-((3-(2-oxo-1,3,4-oxathiazol-5-yl)piperi- din-1-yl)methyl)benzonitrile (3e)}

To a solution of 1-(4-cyano-2-fluorobenzyl)piperidine-3-carboxamide (2e, $300 \mathrm{mg}, 1.15 \mathrm{mmol}$ ) in dioxane $(30 \mathrm{~mL})$ in a three-necked flask, solid $\mathrm{Na}_{2} \mathrm{CO}_{3}(608 \mathrm{mg}$, $5.74 \mathrm{mmol}$ ) and chlorocarbonylsulfenyl chloride $(303 \mathrm{mg}$, $2.30 \mathrm{mmol}$ ) were added under argon. The reaction mixture was stirred at $100{ }^{\circ} \mathrm{C}$ overnight, cooled to room temperature and after the addition of $\mathrm{Et}_{3} \mathrm{~N}(0.75 \mathrm{~mL})$ stirred for 15 minutes. The precipitate was filtered off and the residue concentrated in vacuo. Product was purified with column chromatography using hexane:EtOAc $=3: 1$ as an eluent to give yellow oily product. Yield $=43 \%$; TLC (hexane:EtOAc $=3: 1), \mathrm{R}_{\mathrm{f}}=0.29 ;{ }^{1} \mathrm{H}$ NMR $\left(400 \mathrm{MHz}, \mathrm{DMSO}-d_{6}\right) \delta 1.51-$ $1.56(\mathrm{~m}, 2 \mathrm{H}, \mathrm{H}-5$ and $\mathrm{H}-4), 1.70-1.72(\mathrm{~m}, 1 \mathrm{H}, \mathrm{H}-5)$, 1.91-1.92 (m, 1H, H-4), 2.14-2.19 (m, 1H, H-6), 2.302.35 (m, 1H, H-2), 2.64-2.67 (m, 1H, H-6), 2.91-2.95 (m,

Jukič et al.: Chlorocarbonylsulfenyl Chloride Cyclizations ... 
2H, H-3 and $\mathrm{H}-2), 3.65$ (s, 2H, $\left.\mathrm{CH}_{2}\right), 7.62(\mathrm{t}, J 7.6 \mathrm{~Hz}, 1 \mathrm{H}$, H-5'), 7.69 (dd, J 1.6, 6.4 Hz, 1H, H-2'), 7.83 (dd, J 1.2, 8.4 $\left.\mathrm{Hz}, 1 \mathrm{H}, \mathrm{H}-3^{\prime}\right) ;{ }^{13} \mathrm{C}$ NMR (400 MHz, DMSO-d $) \delta 23.5$ (C-5), 26.0 (C-4), 37.5 (C-3), 52.7 (C-6), 54.2 (C-2), 54.3 $\left(\mathrm{CH}_{2}\right), 111.3(\mathrm{C}-4$ '), $117.7(\mathrm{CN}), 119.3(\mathrm{C}-5), 128.5$ (C-3'), 131.2 (C-1'), 132.2 (C-2'), 158.8 (C-6), 162.4 (NCO), 174.2 (SCO); IR (ATR) v 2947, 2811, 2232, 1758, 1599, 1571, 1496, 1413, 1356, 1260, 1189, 1153, 1089, 1050, 1024, 981, 941, 925, 870,835, 783, 711, 621, $569 \mathrm{~cm}^{-1}$; HRMS-ESI $(m / z):[\mathrm{M}+\mathrm{H}]^{+}$calcd for $\mathrm{C}_{15} \mathrm{H}_{14} \mathrm{FN}_{3} \mathrm{O}_{2} \mathrm{~S}$, 320.0873 , found, 320.0869 .

\section{$N$-(4-((3-(2-oxo-1,3,4-oxathiazol-5-yl)piperidin-1-yl) methyl)phenyl)benzamide (3f)}

To a solution of 1-(4-benzamidobenzyl)piperidine-3-carboxamide (2f, $83 \mathrm{mg}, 0.250 \mathrm{mmol}$ ) in dioxane $(30 \mathrm{~mL})$ in a three-necked flask, solid $\mathrm{Na}_{2} \mathrm{CO}_{3}(130 \mathrm{mg}$, $1.23 \mathrm{mmol}$ ) and chlorocarbonylsulfenyl chloride $(65 \mathrm{mg}$, $0.492 \mathrm{mmol}$ ) were added under argon. The reaction mixture was stirred at $100{ }^{\circ} \mathrm{C}$ overnight, cooled to room temperature and after the addition of $\mathrm{Et}_{3} \mathrm{~N}(0.75 \mathrm{~mL})$ stirred for 15 minutes. The precipitate was filtered off and the residue concentrated in vacuo. Product was purified with column chromatography using hexane:EtOAc $=3: 1$ as an eluent to give yellow oily product. Yield $=16 \%$; TLC (hexane:EtOAc $=3: 1), \mathrm{R}_{\mathrm{f}}=0.07 ;{ }^{1} \mathrm{H}$ NMR $(400 \mathrm{MHz}$, DMSO- $\left.d_{6}\right) \delta 1.02-1.24(\mathrm{~m}, 2 \mathrm{H}, \mathrm{H}-5$ and $\mathrm{H}-4), 1.54-1.56$ (m, 1H, H-5), 1.68 (s, 2H, H-4 and H-6), 2.28-2.30 (m, $1 \mathrm{H}, \mathrm{H}-2), 2.46-2.47(\mathrm{~m}, 1 \mathrm{H}, \mathrm{H}-6), 2.58-2.60(\mathrm{~m}, 1 \mathrm{H}$, $\mathrm{H}-2), 3.02$ (s, 1H, H-3), 3.44-3.55 (m, 2H, CH $), 7.28$ (d, J $8.4 \mathrm{~Hz}, 2 \mathrm{H}, \mathrm{H}-2^{\prime}$ ' and $\mathrm{H}-6$ '), 7.52-7.60 (m, 3H, H-3" and $\mathrm{H}-4$ " and $\mathrm{H}-5$ "), 7.74 (d, J $8.4 \mathrm{~Hz}, 2 \mathrm{H}, \mathrm{H}-3$ ' and $\mathrm{H}-5$ '), 7.94-7.97 (m, 2H, H-2" and H-6"), 10.26 (s, 1H, NH); ${ }^{13} \mathrm{C}$ NMR (400 MHz, $\left.\mathrm{CDCl}_{3}\right) \delta 23.4(\mathrm{C}-5), 27.6(\mathrm{C}-4), 52.9$ (C-3), 54.7 (C-6), $62.1(\mathrm{C}-2), 76.5\left(\mathrm{CH}_{2}\right), 120.2(\mathrm{C}-3$ ' and C-5'), 127.1 (C-2" and C-6"), 128.8 (C-2', C-6, C-3" and C-5”), 129.8 (C-4"), 131.9 (C-1' and C-1"), 134.9 (C-4'), 165.8 (NHCO); IR (ATR) v 2950, 2916, 2868, 2837, 1655, $1601,1523,1458,1410,1376,1319,1258,1167,1098,997$, 973, 841, 809, 168, $694 \mathrm{~cm}^{-1}$; HRMS-ESI $(\mathrm{m} / z):[\mathrm{M}+\mathrm{H}]^{+}$ calcd for $\mathrm{C}_{12} \mathrm{H}_{21} \mathrm{~N}_{3} \mathrm{O}_{3} \mathrm{~S}, 396.1377$, found, 396.1382.

\section{1-Benzylpiperidine-3-carbonitrile (4a)}

In a three-necked flask 1-benzyl piperidine-3-carboxamide (2a, $100 \mathrm{mg}, 0.458 \mathrm{mmol}$ ) was dissolved in pyridine $(5 \mathrm{~mL})$. Solution was cooled on ice and chlorocarbonylsulfenyl chloride $(120 \mathrm{mg}, 0.916 \mathrm{mmol})$ was added dropwise under argon. The reaction mixture was stirred at $80^{\circ} \mathrm{C}$ overnight, cooled to room temperature and after the addition of $\mathrm{Et}_{3} \mathrm{~N}(0,32 \mathrm{~mL})$ stirred for 15 minutes. The precipitate was filtered off and the residue concentrated in vacuo. Product was purified with column chromatography using DCM: $\mathrm{MeOH}=9: 1$ as an eluent to give a pure brownish solid. Yield = $33 \%$; TLC (DCM:MeOH = 9:1), $\mathrm{R}_{\mathrm{f}}$ $=0.95 ;{ }^{1} \mathrm{H} \mathrm{NMR}\left(400 \mathrm{MHz}, \mathrm{DMSO}-d_{6}\right) \delta 1.54(\mathrm{~s}, 1 \mathrm{H}$, $\mathrm{H}-4), 1.67$ (s, 3H, H-4 and H-5), 2.27-2.28 (m, 1H, H-6),
2.46-2.55 (m, 2H, H-2 and H-3), 2.59 (s, 1H, H-6), 3.01 (s, 1H, H-2), 3.50-3.57 (m, 2H, $\left.\mathrm{CH}_{2}\right), 7.26-7.36(\mathrm{~m}, 5 \mathrm{H}$, ArH); ${ }^{13} \mathrm{C}$ NMR (400 MHz, DMSO-d $) \delta 22.8$ (C-5), 26.6 (C-4), $42.3(\mathrm{C}), 53.1$ (C-6), $55.8(\mathrm{C}-2), 61.5\left(\mathrm{CH}_{2}\right), 121.8$ (CN), 126.9 (C-4'), 128.1, 128.2, 128.4, 128.6 (C-2',3',5',6'), 137.8 (C-1'); IR (ATR) v 2943, 2804, 2766, 2240, 1493, 1452, 1393, 1349, 1309, 1257, 1205, 1151, 1099, 1072, 1011, $985,959,911,868,773,604,565,542,510 \mathrm{~cm}^{-1} ; \mathrm{MS} \mathrm{m} / z$ (relative intensity): $201.1(\mathrm{M}+\mathrm{Na}, 100)$; HRMS-ESI $(\mathrm{m} / z)$ : $[\mathrm{M}+\mathrm{H}]^{+}$calcd for $\mathrm{C}_{14} \mathrm{H}_{16} \mathrm{~N}_{2} \mathrm{O}_{2} \mathrm{~S}, 201.1397$, found, 201.1392.

\section{1-(4-Nitrobenzyl)piperidine-3-carbonitrile (4b)}

In a three-necked flask 1-(4-nitrobenzyl)piperidine-3-carboxamide (2b, $100 \mathrm{mg}, 0.380 \mathrm{mmol}$ ) was dissolved in pyridine $(10 \mathrm{~mL})$. The solution was cooled on ice and chlorocarbonylsulfenyl chloride (100 mg, 0.760 $\mathrm{mmol}$ ) was added under argon. The reaction mixture was stirred at $80^{\circ} \mathrm{C}$ overnight, cooled to room temperature and after the addition of $\mathrm{Et}_{3} \mathrm{~N}(0.32 \mathrm{~mL})$ stirred for 15 minutes. The precipitate was filtered off and the residue concentrated in vacuo. Product was purified with column chromatography using DCM:MeOH = 9:1 as an eluent to give a brownish solid. Yield = $34 \%$; TLC (DCM:MeOH = 9:1) $\mathrm{R}_{\mathrm{f}}$ $=0.96 ;{ }^{1} \mathrm{H}$ NMR $\left(400 \mathrm{MHz}, \mathrm{CDCl}_{3}\right) \delta 1.64-1.65(\mathrm{~m}, 1 \mathrm{H}$, $\mathrm{H}-5$ ), 1.79-1.85 (m, 3H, H-5 and H-4), 2.46 (s, 2H, H-6), 2.63 (s, 2H, H-2), 2.81-2.84 (m, 1H, H-3), 3.63 (dd, J 6.8, $14.4 \mathrm{~Hz}, 2 \mathrm{H}, \mathrm{CH}_{2}$ ), 7.53 (d, 2H, H-2' and $\mathrm{H}-6$ '), 8.19 (dd, J 2.0, $4.8 \mathrm{~Hz}, 2 \mathrm{H}, \mathrm{H}-3$ ' and $\mathrm{H}-5$ '); ${ }^{13} \mathrm{C} \mathrm{NMR}(400 \mathrm{MHz}$, $\left.\mathrm{CDCl}_{3}\right) \delta 23.4(\mathrm{C}-5), 27.4(\mathrm{C}-4), 27.9(\mathrm{C}-3), 53.3(\mathrm{C}-6)$, $55.1(\mathrm{C}-2), 61.7\left(\mathrm{CH}_{2}\right), 121.0(\mathrm{CN}), 123.7\left(\mathrm{C}-3^{\prime}\right.$ and $\left.\mathrm{C}-5^{\prime}\right)$, 129.2 (C-2' and C-6'), 145.8 (C-1'), 147.3 (C-4'); IR $(\mathrm{ATR}) \vee 2945,2802,2240,1599,1467,1439,1154,1093$, $1033,1012,990,955,801,773,696,651,547 \mathrm{~cm}^{-1} ; \mathrm{MS} \mathrm{m} / z$ (relative intensity): $246.1(\mathrm{M}+\mathrm{Na}, 100)$; HRMS-ESI $(\mathrm{m} / z)$ : $[\mathrm{M}+\mathrm{H}]^{+}$calcd for $\mathrm{C}_{14} \mathrm{H}_{15} \mathrm{~N}_{3} \mathrm{O}_{4} \mathrm{~S}, 246.1242$, found, 246.1243.

\section{Conclusion}

Based on the previously reported oxathiazol-2one-bearing and nonpeptidic inhibitors of the chymotrypsin-like $(\beta 5 \mathrm{i})$ subunit of the immunoproteasome, we designed a novel series of piperidin-3-yl-oxathiazol-2-ones as potential covalent inhibitors of threonine proteases. Compounds were designed with a synthetically accessible piperidine central core derivatized with an oxathiazol-2-one electrophilic moiety. In lieu of previously reported synthetic approaches, we identified a synthetic protocol that enables the cyclization of carboxamides incorporating a basic centre into oxathiazol-2-ones. This straightforward protocol using chlorocarbonylsulfenyl chloride as a reagent in dioxane afforded the desired products in moderate to good yields. Thus, a vast chemical space of 5-substituted oxathiazol-2-ones can be explored and various chemical libraries of inhibitors of threonine proteases can be compiled. 


$\begin{array}{ll}\text { Abbreviations } \\ \text { ATR IR } & \text { attenuated total reflectance infrared spectroscopy } \\ \text { BDMS } & \text { bromodimethylsulfonium bromide } \\ \mathrm{CDCl}^{3} & \text { deuterated chloroform } \\ \text { DBU } & \text { 1,8-diazabicyclo(5.4.0) undec-7-ene } \\ \text { DCM } & \text { dichloromethane } \\ \text { DMSO } & \text { dimethyl sulfoxide } \\ \text { DMF } & \text { dimethylformamide } \\ \text { EtOAc } & \text { ethyl acetate } \\ \text { MTB } & \text { Mycobacterium tuberculosis } \\ \text { Py } & \text { pyridine } \\ \text { THF } & \text { tetrahydrofuran } \\ \text { TLC } & \text { thin-layer chromatography }\end{array}$

\section{Conflict of interest}

The authors declare they have no conflict of interest.

\section{Acknowledgments}

The authors acknowledge the financial support from the Slovenian Research Agency (research core funding No. P1-0208). We thank Dr. Dušan Žigon (Mass Spectrometry Center, Jožef Stefan Institute, Ljubljana, Slovenia) for mass spectra.

\section{References}

1. M. Drag, G. S. Salvesen, Nat. Rev. Drug Discov. 2010, 9, 690701. DOI: $10.1038 / \mathrm{nrd} 3053$

2. D. H. Lee, A. L. Goldberg, Trends Cell Biol. 1998, 8, 397-403. DOI:10.1016/S0962-8924(98)01346-4

3. C. H Arrowsmith, J. E. Audia, C. Austin, J. Baell, J. Bennett, J. Blagg, C. Bountra, P. E. Brennan, P. J. Brown, M. E. Bunnage, C. Buser-Doepner, R. M. Campbell, A. J. Carter, P. Cohen, R. A. Copeland, B. Cravatt, J. L. Dahlin, D. Dhanak, A. M. Edwards, M. Frederiksen, S. V. Frye, N. Gray, C. E. Grimshaw, D. Hepworth, T. Howe, K. V. M. Huber, J. Jin, S. Knapp, J. D. Kotz, R. G. Kruger, D. Lowe, M. M. Mader, B. Marsden, A. Mueller-Fahrnow, S. Müller, R. C. O’Hagan, J. P. Overington, D. R. Owen, S. H. Rosenberg, R. Ross, B. Roth, M. Schapira, S. L. Schreiber, B. Shoichet, M. Sundström, G. Superti-Furga, J. Taunton, L. Toledo-Sherman, C. Walpole, M. A. Walters, T. M. Willson, P. Workman, R. N. Young, W. J. Zuercher, Nat. Chem. Biol. 2015, 11, 536-541.

DOI: $10.1038 /$ nchembio. 1867

4. N. D. Rawlings, E. O’Brien, A. J. Barrett, Nucleic Acids Res. 2002, 30, 343-346.

DOI:10.1093/nar/30.1.343

5. E. M. Huber, M. Groll, Angew. Chem. Int. Ed. 2012, 51, 87088720. DOI:10.1002/anie.201201616

6. L. R. Dick, P. E. Fleming, Drug Discov. Today 2010, 15.5, 243 249. DOI:10.1016/j.drudis.2010.01.008

7. D. A. Ferrington, D. S. Gregerson, Prog. Mol. Biol. Transl. Sci. 2012, 109, 75-112.

DOI:10.1016/B978-0-12-397863-9.00003-1
8. A. Schweitzer, A. Aufderheide, T. Rudack, F. Beck, G. Pfeifer, J. M. Plitzko, E. Sakata, K. Schulten, F. Förster, W. Baumeister, Proc. Natl. Acad. Sci. 2016, 113, 7816-21.

DOI:10.1073/pnas.1608050113

9. R. Raynes, L. C. D. Pomatto, K. Davies, J. A. Kelvin, Mol. Aspects Med. 2016, 50, 41-55.

DOI:10.1016/j.mam.2016.05.001

10. M. Schmidt, D. Finley, Biochim. Biophys. Acta - Molecular Cell Research 2014, 1843, 13-25.

11. A. F. Kisselev, W. A. Van Der Linden, H. S. Overkleeft, Chem. Biol. 2012, 19, 99-115.

DOI:10.1016/j.chembiol.2012.01.003

12. M. Groll, Y. Koguchi, R. Huber, J. Kohno, J. Mol. Biol. 2001, 311, 543-548. DOI:10.1006/jmbi.2001.4869

13. E. M. Huber, M. Basler, R. Schwab, W. Heinemeyer, C. J. Kirk, M. Groettrup, M. Groll, Cell 2012, 148, 727-738.

DOI:10.1016/j.cell.2011.12.030

14. M. Groll, K. B. Kim, N. Kairies, R. Huber, C. M. Crews, J. Am. Chem. Soc. 2000, 122, 1237-1238.

DOI:10.1021/ja993588m

15. H. W. B. Johnson, J. L. Anderi, E. K. Bradley, J. Bui, J. Jones, S. Arastu-Kapur, L. M. Kelly, E. Lowe, D. C. Moebius, T. Muchamuel, C. Kirk, Z. Wang, D. McMinn, Med. Chem. Lett. 2017, 8, 413-417. DOI:10.1021/acsmedchemlett.6b00496

16. I. Sosič, M. Gobec, B. Brus, D. Knez, M. Živec, J. Konc, S. Lešnik, M. Ogizek, A. Obreza, D. Žigon, D. Janežic, I. Mlinarič-Raščan, S. Gobec, Angew. Chem. Int. Ed. 2016, 55, 57455748. DOI:10.1002/anie.201600190

17. C. Dubiella, R. Baur, H. Cui, E. M. Huber, M. Groll, Angew. Chem. Int. Ed. 2015, 54, 15888-15891.

DOI:10.1002/anie.201506631

18. G. Lin, D. Li, L. P. S. de Carvalho, H. Deng, H. Tao, G. Vogt, K. Wu, J. Schneider, T. Chidawanyika, J. D. Warren, H. Li, C. Nathan, Nature 2009, 461, 621-626.

DOI:10.1038/nature08357

19. J. Schrader, F. Henneberg, R. A. Mata, K. Tittmann, T. R. Schneider, H. Stark, G. Bourenkov, A. Chari, Science 2016, 353, 594-598. DOI:10.1126/science.aaf8993

20. J. Singh, R. C. Petter, T. A. Bailie, A. Whitty, Nat. Rev. Drug Discov. 2011, 10, 307-317. DOI:10.1038/nrd3410

21. H. Fan, N. G. Angelo, J. D. Warren, C. F. Nathan, G. Lin, Med. Chem. Lett. 2014, 5, 405-410. DOI:10.1021/ml400531d

22. B. E. Gryder, W. Guerrant, C. H. Chen, A. K. Oyelere, Med. Chem. Comm. 2011, 2, 1083-1086. DOI:10.1039/c1md00208b

23. C. Kuo, J. Zhu, J. Wu, C. Chu, C. Yao, K. Shia, Chem. Comm. 2007, 3, 301-303. DOI:10.1039/B614061K

24. A. S. Gurjar, V. Andrisano, A. D. Simone, V. S. Velingkar, Bioorg. Chem. 2014, 57, 90-98. DOI:10.1016/j.bioorg.2014.09.002

25. B. Rickborn, F. R. Jensen, J. Org. Chem. 1962, 27, 4608-4610. DOI:10.1021/jo01059a114

26. K. Mai, G. Patil, Tetrahedron Lett. 1986, 27, 2203-2206. DOI:10.1016/S0040-4039(00)84487-1

27. D. A. Claremon, B. T. Phillips, Tetrahedron Lett. 1988, 29, 2155-2158. DOI:10.1016/S0040-4039(00)86697-6 
28. T. M. Bargar, C. M. Riley, Syn. Comm. 1980, 10, 479-487. DOI:10.1080/00397918008064272

29. L. D. S. Yadav, V. P. Srivastava, R. Patel., Tetrahedron Lett. 2009, 50, 5532-5535. DOI:10.1016/j.tetlet.2009.07.100

30. S. I. Maffioli, E. Marzorati, A. Marazzi, Org. Lett. 2005, 7, 5237-5239. DOI:10.1021/ol0521001

31. N. Nakajima, M. Ubukata, Tetrahedron Lett. 1997, 38, 2099 2102. DOI:10.1016/S0040-4039(97)00316-X

32. W. E. Dennis, J. Org. Chem. 1970, 35, 3253-3255. DOI:10.1021/jo00835a016

33. S. Zhou, K. Junge, D. Addis, S. Das, M. Beller, Org. Lett. 2009, 11, 2461-2464. DOI:10.1021/ol900716q

34. A. Aitha, S. Yennam, M. Behera, J. S. Anireddy, Tetrahedron
Lett. 2016, 57, 1507-1510.

DOI:10.1016/j.tetlet.2016.02.082

35. P. C. Unangst, G. P. Shrum, D. T. Connor, J. Heterocycl. Chem. 1993, 30, 357-359. DOI:10.1002/jhet.5570300211

36. J. Crosby, M. C. McKie, M. Paton, J. F. Ross, Arkivoc 2000, 1, 720-734.

37. R. M. Paton, Chem. Soc. Rev. 1989, 18, 33-52.

DOI:10.1039/cs9891800033

38. R. K. Howe, T. A. Gruner, L. G. Carter, L. L. Black, J. E. Franz. J. Org. Chem. 1978, 43, 3736-3742.

DOI:10.1021/jo00413a024

39. P. Öhrngren, A. Fardost, F. Russo, J. S. Schanche, M. Fagrell, M. Larhed, Org. Process Res. Dev. 2012, 16, 1053-1063.

\section{Povzetek}

$\mathrm{Z}$ zamenjavo molekulskega skeleta smo načrtovali spojine s piperidinskim jedrom, derivatiziranim $\mathrm{z}$ oksatiazol-2-onskim elektrofilnim centrom, ki omogoča selektivno zaviranje treoninskih proteaz. Sinteza produktov po postopkih, opisanih v literaturi, ni bila uspešna, poleg tega smo identificirali nitrile kot glavne stranske produkte, ki nastanejo pri dehidraciji karboksamidne funkcionalne skupine. S sistematično optimizacijo reakcijskih pogojev, smo s segrevanjem karboksamidov, klorokarbonilsulfenil klorida in natrijevega karbonata kot baze v dioksanu pri $100{ }^{\circ} \mathrm{C}$ pripravili serijo piperidin-3-il-oksatiazol-2-onov, primerno za nadaljnje biološko vrednotenje. 